\title{
Emocje estetyczne w świetle badań psychologii muzyki: opis i mechanizmy wyjaśniające
}

DOI: $10.14746 /$ rfn.2018.19.1

Muzyka jest najbardziej abstrakcyjną ze sztuk, ma jednak niesamowitą moc wywoływania realnych przeżyć - emocji. Emocja doświadczana w pełni ma swoje objawy fizjologiczne (zmiany w systemie neuroendokrynnym, zmiany poziomu pobudzenia), behawioralne (zmiany w mimice, postawie ciała, działaniu) oraz poznawcze (ocenianie, sądy). Te zmiany są zazwyczaj zsynchronizowane ze sobą i pojawiają się w reakcji na wydarzenia ważne z punktu widzenia potrzeb i celów podmiotu ${ }^{1}$. Wydawałoby się, że emocje pojawiające się podczas słuchania muzyki przejawiają się w podobny sposób: odczuwamy przyśpieszone bicie serca, dreszcze, gęsią skórkę podczas słuchania Lamentu Dydony z opery Dydona $i$ Eneasz Henry'ego Purcella, zmieniamy postawę na wyprostowaną, otwartą podczas fragmentu Allegro z V Koncertu fortepianowego „Cesarskiego" Ludwiga van Beethovena, poddajemy głębokiej refleksji nasze życie, słuchając Arii na strunie G Jana Sebastiana Bacha.

Szereg badaczy twierdzi jednak, że emocje przeżywane $\mathrm{w}$ kontakcie $\mathrm{z}$ dziełem sztuki (emocje estetyczne) nie są tożsame $\mathrm{z}$ emocjami przeżywanymi na co dzień. Emocje podstawowe, takie jak radość,

1 K.R. Scherer, Emotion as a Process: Function, Origin, and Regulation, „Social Science Information” $1982 \mathrm{nr} 21$, s. 555; idem, What Are Emotions? And How Can They Be Measured?, „Social Science Information" $2005 \mathrm{nr}$ 44, s. 697-699. smutek, złość, strach, wstręt i zaskoczenie ${ }^{2}$, stanowią pewne programy biologiczne, uruchamiane automatycznie w odpowiedzi na wydarzenia ważne z punktu widzenia przetrwania jednostki. Emocje estetyczne nie służą takim celom, wzbudzane są w wyniku oceny poznawczej bodźca lub sytuacji estetycznej i są nierozerwalnie związane $z$ systemem indywidualnych ocen i wartości każdego $\mathrm{z}$ nas ${ }^{3}$. Wyniki badań potwierdzają obserwacje życiowe: słuchaniu muzyki nie zawsze towarzyszą reakcje emocjonalne ${ }^{4}$. Pokazują także, że muzyka wywołuje reakcje emocjonalne średnio u 55-65\% respondentów i są to codzienne, uniwersalne emocje (opisywane najczęściej w wymiarach spokój-zrelaksowanie, radość-szczęście, zaciekawienie-oczekiwanie ${ }^{5}$ ). Emocje estetyczne, uważane przez

2 Por. P. Ekman, An Argument for Basic Emotions, „Cognition and Emotion” 1992 nr 6, s. 175-176; por. także C.E. Izard, Basic Emotions, Natural Kinds, Emotion Schemas, and a New Paradigm, „Perspectives on Psychological Science” 2007 nr 2, s. 265-266.

3 P. Kivy, Music Alone: Philosophical Reflections on the Purely Musical Experience, Ithaca 1990, s. 41; L.B. Meyer, Emocja i znaczenie $w$ muzyce, przeł. A. Buchner, K. Berger, Kraków 1974, s. 46-47, 54-57.

4 Por. „muzyka tła”, „tapeta dźwiękowa”; S. Makomaska, Droga do „makdonaldyzacji” doświadczenia stuchowego - refleksja nad obecnościa muzyki tła w przestrzeni komercyjnej, [w:] Psychologia muzyki. Pomiędzy wykonawca a odbiorca, red. J. Kaleńska-Rodzaj, R. Lawendowski, Gdańsk 2015, s. 151-152.

5 P.N. Juslin, P. Laukka, Expression, Perception, and Induction of Musical Emotions: A Review and a Questionnaire Study of Everyday Listening, „Journal of New Music Research” 2004 nr 33, s. 230. 
cytowanych autorów za specyficzne dla muzyki jako dzieła sztuki (podziw, zachwyt, przerażenie), odczuwane są rzadko ${ }^{6}$ lub wcale ${ }^{7}$.

Podkreślany jest również problem genezy emocji czy mechanizmy powstawania emocji estetycznych są inne niż w przypadku emocji odczuwanych na co dzień? Niektórzy badacze wiążą emocje estetyczne $\mathrm{z}$ wyjątkowo intensywnymi, osadzonymi w ciele (ang. embodied) doznaniami ${ }^{8}$. Z kolei inni wskazują, że poziom pobudzenia podczas takich doznań wcale nie musi być wysoki, ponieważ te emocje mają refleksyjny, abstrakcyjny charakter i osadzone są w mniej realnej, a bardziej wirtualnej przestrzeni mentalnej związanej ze słuchaniem muzyki ${ }^{9}$.

Trzecim ważnym zagadnieniem jest problem nazewnictwa emocji estetycznych - szereg badaczy zwraca uwagę na to, że listy emocji tradycyjnie wykorzystywane w badaniach nie nadają się do badania emocji estetycznych, które mają bardziej złożony, a zarazem subtelny charakter.

Celem tego tekstu jest dokonanie przeglądu współczesnych badań nad emocjami estetycznymi z perspektywy psychologii muzyki. Poglądy kluczowych badaczy emocji estetycznych zostaną zestawione ze współczesną wiedzą na temat mechanizmów powstawania emocji podstawowych i złożonych. Spodziewam się, że analiza wyników badań w szerszym kontekście teoretycznym pozwoli odpowiedzieć na pytanie, czy zasadne jest wyodrębnianie osobnej kategorii emocji estetycznych oraz muzycznych emocji estetycznych.

\section{TYPOLOGIA EMOCJI ESTETYCZNYCH}

Ze względu na istnienie wielu definicji samego pojęcia „emocja”, pojęcie „emocji estetycznych" ${ }^{10}$ również

${ }^{6}$ V.J. Konecni, The Aesthetic Trinity: Awe, Being Moved, Thrills, „Bulletin Psychology and the Arts” 2005 nr 5, s. 36; M. Zentner D. Grandjean, K.R. Scherer, Emotions Evoked by the Sound of Music: Characterization, Classification, and Measurement, „Emotion” 2008 t. 8 nr 4, s. 516.

A. Gabrielsson, Emotion Perceived and Emotion Felt: Same or Different?, „Musicae Scientiae” 2002 t. 5 nr 1, s. 134.

${ }^{8}$ Por. SEM, Strong Experience with Music, A. Gabrielsson, S. Lindström Wik, Strong Experiences Related to Music: A Descriptive System, „Musicae Scientiae” 2003 t. 7 nr 2, s. 170-171.

9 Por. M. Zentner i in., Emotions..., op. cit., s. 515.

${ }^{10}$ Jako przeciwieństwa emocji codziennych, podstawowych (ang. utilitarian emotions), por. K.R. Scherer, Which Emotions Can Be nie jest klarowne. W literaturze naukowej z zakresu sztuki termin „emocje estetyczne” używany jest dwojako: w szerokim znaczeniu, jako wszystkie codzienne, podstawowe lub złożone emocje pojawiające się w kontakcie z dziełem sztuki ${ }^{11}$, jak i w wąskim - jako unikalne, specyficzne dla danego gatunku sztuki odpowiedzi emocjonalne ${ }^{12}$. Pierwszy pogląd - egalitarny zakłada, że bodziec muzyczny, jak każdy inny bodziec, może wywoływać emocje u odbiorcy, a złożoność odczuwanych emocji zależy od indywidualnych doświadczeń, stopnia refleksji nad nimi oraz wglądu we własne życie emocjonalne ${ }^{13}$. Drugie, elitarne podejście do muzycznych emocji estetycznych ${ }^{14}$ jest dość kontrowersyjne, zakłada bowiem istnienie specyficznie muzycznych emocji i odrębnych mechanizmów ich wzbudzania w odpowiedzi na bodźce muzyczne. Poniżej zostaną przedstawione argumenty zwolenników każdego $\mathrm{z}$ wymienionych podejść.

W latach osiemdziesiątych Alf Gabrielsson zapoczątkował projekt, który miał na celu zbadanie i opisanie silnych doświadczeń muzycznych jako „doświadczeń szczytowych" (ang. peak experience) ${ }^{15}$ na gruncie muzyki. Szeroko zakrojone badania jakościowe ${ }^{16}$ na dużej grupie słuchaczy i wykonawców pozwoliły wyodrębnić siedem podstawowych kategorii opisowych silnych doświadczeń związanych z muzyką: cechy ogólne (np. unikalne, niepoddające się opisowi, fantastyczne); reakcje fizyczne i/lub behawioralne; percepcja (np. wzrokowa, słuchowa, kinestetyczna,

Induced by Music? What Are the Underlying Mechanisms? And How Can We Measure Them?, „Journal of New Music Research” 2004 nr 33, s. 241.

${ }^{11}$ J. Levinson, Music and Negative Emotion, [w:] Music and Meaning, red. J. Robinson, Ithaca-London 1997, s. 217-218; mechanizm powstawania emocji w kontakcie z muzyką oparty jest, zdaniem Levinsona, na empatii i odzwierciedleniu, por. s. 228-229.

${ }_{12}$ P.N. Juslin, Music and Emotion: Seven Questions, Seven Answers, [w:] Music and the Mind: Essays in Honour of John Sloboda, red. I. Deliège, J. Davidson, New York 2011, s. 125, 127.

${ }^{13}$ M. Lewis, Wyłanianie się ludzkich emocji, [w:] Psychologia emocji, red. M. Lewis, J. Haviland-Jones, przeł. M. Kacmajor i in., Gdańsk 2005, s. 358.

${ }^{14}$ Emocje te określane są po angielsku jako music-induced emotions, w tekście źródłowym często jednak używane jest określenie musical emotions; por. M. Zentner i in., Emotions..., op. cit., s. 495.

15 A.H. Maslow, Toward a Psychology of Being, New York 1968, s. 71.

16 Analiza jakościowa 400 opisów doświadczeń uzyskanych od 300 osób badanych; por. A. Gabrielsson, Emotions in Strong Experiences with Music, [w:] Music and Emotion. Theory and Research, red. P.N. Juslin, J.A. Sloboda, Oxford 2001, s. 434. 
synestetyczna); poznanie (np. zmiana nastawienia, zmiana perspektywy czasowej, wspomnienia); aspekty egzystencjalne i transcendentalne (np. sens istnienia, doświadczenia religijne); osobisty rozwój (np. nowy wgląd, poczucie przynależności) oraz emocje. Z punktu widzenia podjętego tematu warto szerzej opisać ostatnią kategorię, w ramach której wyróżniono:

1) emocje intensywne o wysokim (niekontrolowalne, przerażające) lub niskim (spokój ducha ${ }^{17}$, nostalgia) natężeniu;

2) emocje pozytywne, wśród których najczęściej wymieniane były szczęście, radość, podniecenie, błogość, czasem opisywane jako euforia, ekstaza;

3) emocje negatywne, np. smutek, frustracja, które najczęściej jednak były skutkiem wspomnień wydarzeń życiowych wywołanych muzyką;

4) emocje mieszane (konfliktowe), najczęściej doświadczane sekwencyjnie - np. uczucie bycia wstrząśniętym i zszokowanym, które stopniowo ustępuje poczuciu przyjemności, lub poczucie zmieszania, spowodowane szybkimi zmianami emocji podyktowanymi utworem.

Warto zauważyć, że wymienione emocje mogą być wywoływane nie tylko muzyką, lecz także całym kontekstem, w którym dzieło jest prezentowane i odbierane: sytuacja estetyczna ${ }^{18}$ jest współtworzona przez właściwości dzieła, wykonawcy, odbiorcy oraz czynniki sytuacyjne, które stają się źródłami muzycznych doświadczeń emocjonalnych. Te silne doświadczenia z kolei mogą zapoczątkować zaangażowanie w muzykę na długie lata ${ }^{19}$.

Wśród opisów emocji zebranych przez Gabrielssona znajdujemy zarówno nazwy emocji podstawowych, jak i złożonych, estetycznych, związanych ze wzniosłymi uczuciami piękna, harmonii. Nie wyodrębnia on specyficznie muzycznych emocji estetycznych, choć wskazuje na rozwojowe, transcendentalne, duchowe funkcje emocji odczuwanych w kontakcie $\mathrm{z}$ utworem muzycznym. Relacjonuje także zgłaszany przez osoby badane problem dotyczący werbalnego opisu

\footnotetext{
17 Tłumaczenie angielskiej nazwy emocji peacefulness.

${ }_{18}$ M. Gołaszewska, Kim jest artysta?, Warszawa 1986, s. 10-11.

19 Por. B. Kamińska, Znaczace przeżycia muzyczne w relacjach młodzieży, [w:] Powszechna edukacja muzyczna a wyzwania wspótczesności, red. A. Białkowski, Lublin 2000, s. 193; J.A. Sloboda, Poznanie, emocje, wykonanie - trzy wykłady z psychologii muzyki, Warszawa 1999, s. 37.
}

emocji estetycznych za pomocą już istniejących określeń emocjonalnych ${ }^{20}$.

Problem braku terminologii i klasyfikacji muzycznych emocji estetycznych postanowił rozwiązać Marcel Zentner wraz ze współpracownikami ${ }^{21}$. Badacze podjęli się ważnego zadania stworzenia taksonomii emocji wywoływanych muzyką. W wyniku serii czterech eksperymentów przeprowadzonych na grupie prawie 1500 słuchaczy autorom udało się sformułować leksykon określeń używanych w języku angielskim do opisu emocji odczuwanych w kontakcie z muzyką, a także wyodrębnić nadrzędne kategorie muzycznych emocji estetycznych.

W wyniku kilkustopniowej rygorystycznej selekcji określeń emocjonalnych związanych z muzyką z ponad 500 nazw emocji wyselekcjonowano ostatecznie 40 określeń emocjonalnych. Jako ciekawostkę warto podać fakt, że za emocje niemuzyczne osoby badane uznały m.in. poczucie winy, wstyd, pogardę, wstręt, zażenowanie i zazdrość. Wyselekcjonowane w wyniku serii czterech eksperymentów emocje estetyczne wraz z nadrzędnymi czynnikami przedstawia tabela 1 .

Tabela 1. Taksonomia emocji estetycznych - wymiary Genewskiej Skali Emocji Muzycznych ${ }^{22}$

\begin{tabular}{|c|l|l|}
\hline $\begin{array}{c}\text { Czynniki } \\
\text { nadrzędne }\end{array}$ & $\begin{array}{c}\text { Kategorie } \\
\text { emocji } \\
\text { estetycznych }\end{array}$ & \multicolumn{1}{|c|}{ Emocje estetyczne } \\
\hline \multirow{5}{*}{ Wzniosłość } & podziw & $\begin{array}{l}\text { szczęśliwy, zdumiony, } \\
\text { oślepiony, przytłoczony, } \\
\text { wzruszony }\end{array}$ \\
\cline { 2 - 3 } & transcendencja & $\begin{array}{l}\text { zainspirowany, } \\
\text { przeniesiony winny } \\
\text { wymiar, uduchowiony, } \\
\text { wstrząśnięty }\end{array}$ \\
\cline { 2 - 3 } & czułość & $\begin{array}{l}\text { zakochany, tkliwy, } \\
\text { zmysłowy, delikatny, } \\
\text { łagodny }\end{array}$ \\
\hline
\end{tabular}

${ }^{20}$ Por. A. Gabrielsson, Emotions in Strong Experiences with $\mathrm{Mu}$ sic..., op. cit., s. 435 .

${ }_{21}$ M. Zentner i in., Emotions..., op. cit., s. 496. Prace nad polską adaptacją skali prowadzi Maria Chełkowska-Zacharewicz; por. M. Chełkowska-Zacharewicz, M. Janowski, Polska adaptacja Geneva Emotional Music Scale (GEMS) - badania wstępne, „Polskie Pismo Muzykoterapeutyczne" 2016 nr 3, s. 44-64.

${ }_{22}$ Tłumaczenie na język polski angielskich nazw emocji jest zadaniem dość trudnym, biorąc pod uwagę różnice kulturowe związane z zawartością treściową pojęć (por. A. Wierzbicka, Emotions Across Languages and Cultures, Cambridge 1999). Przed zastosowaniem przedstawionego narzędzia niezbędna byłaby jego adaptacja do warunków polskich. 


\begin{tabular}{|c|l|l|}
\hline $\begin{array}{c}\text { Czynniki } \\
\text { nadrzędne }\end{array}$ & \multicolumn{1}{|c|}{$\begin{array}{c}\text { Kategorie } \\
\text { emocji } \\
\text { estetycznych }\end{array}$} & \multicolumn{1}{|c|}{ Emocje estetyczne } \\
\hline Wzniosłość & nostalgia & $\begin{array}{l}\text { sentymentalny, } \\
\text { rozmarzony, } \\
\text { nostalgiczny, } \\
\text { melancholijny }\end{array}$ \\
\cline { 2 - 3 } & spokój ducha & $\begin{array}{l}\text { spokojny, zrelaksowany, } \\
\text { pogodny, ukojony, } \\
\text { zamyślony }\end{array}$ \\
\hline \multirow{4}{*}{ Witalność } & energia & $\begin{array}{l}\text { pełen energii, } \\
\text { tryumfujący, } \\
\text { rozpłomieniony, mocny, } \\
\text { heroiczny }\end{array}$ \\
\cline { 2 - 3 } & $\begin{array}{l}\text { radosna } \\
\text { aktywacja }\end{array}$ & $\begin{array}{l}\text { pobudzony, wesoły, } \\
\text { żwawy, roztańczony, } \\
\text { rozbawiony }\end{array}$ \\
\hline \multirow{2}{*}{ Niepokój } & napięcie & $\begin{array}{l}\text { poruszony, nerwowy, } \\
\text { spięty, zniecierpliwiony, } \\
\text { poirytowany }\end{array}$ \\
\cline { 2 - 3 } & smutek & \begin{tabular}{l} 
smutny, rozżalony \\
\hline
\end{tabular}
\end{tabular}

Źródło: opracowanie własne na podstawie M. Zentner i in. ${ }^{23}$

Podczas kolejnego badania, przeprowadzonego tym razem $w$ terenie $w$ ramach festiwalu muzycznego, cytowani autorzy zestawili częstotliwość wyborów poszczególnych emocji odczuwanych przez słuchaczy. Okazało się, że z listy najczęściej (30-45\% respondentów) wybierane były emocje pozytywne (zrelaksowany, szczęśliwy, wesoły, rozmarzony, pobudzony, roztańczony,), a najrzadziej (mniej niż 4\% respondentów) - negatywne (zły, przygnębiony, rozżalony, przestraszony, agresywny). Zauważono również, że emocje wywołane muzyką często mają postać emocji mieszanych, złożonych stanów emocjonalnych.

$\mathrm{W}$ jednym $\mathrm{z}$ badań cytowani autorzy porównali ze sobą opisy wrażeń emocjonalnych fanów pięciu poszczególnych gatunków muzyki (poważna, jazz, pop/rock, techno, muzyka latynoamerykańska). Zadaniem osób badanych było opisanie emocji powstających podczas słuchania ulubionego gatunku muzyki. Emocje wspólne dla wszystkich gatunków pochodziły z kategorii „spokój ducha” oraz częściowo - „podziw” $\mathrm{i}$ „czułość”. Jest to spójne $\mathrm{z}$ wnioskami $\mathrm{z}$ innych badań ${ }^{24}$, wskazującymi na przewagę $\mathrm{w}$ doświadczeniu

\footnotetext{
23 M. Zentner i in., Emotions..., op. cit., s. 507.

24 Por. P.N. Juslin, P. Laukka, Expression..., op. cit., s. 231, a także P. Laukka, Uses of Music and Psychological Well-Being among the Elderly, „Journal of Happiness Studies” 2007 nr 8, s. 224.
}

słuchaczy pozytywnych emocji wywołanych muzyką nad negatywnymi.

Wyniki kolejnego eksperymentu z opisywanej serii, porównującego emocje odczuwane w kontakcie $\mathrm{z}$ muzyką $\mathrm{z}$ emocjami odczuwanymi w sytuacjach codziennych, można zinterpretować także jako odpowiedź na pytanie, dlaczego fani cenią dany gatunek muzyczny. Wielbiciele muzyki klasycznej, słuchając ulubionego gatunku muzyki, najczęściej przeżywali podziw, uspokojenie, uduchowienie, poczucie mocy; jazzu - podziw, radość, uspokojenie; popu/rocka podziw, radość, aktywację; muzyki latynoamerykańskiej - radość, energię, aktywację; techno - radość, aktywację.

Dzięki pomysłowości eksperymentów oraz wykorzystaniu zaangażowanych technik analizy statystycznej Zentner z zespołem stworzyli i starannie przetestowali swój wielowymiarowy model muzycznych emocji estetycznych, udowodniając, że lepiej nadaje się on do opisu emocji estetycznych ${ }^{25}$ niż modele alternatywne - model emocji podstawowych ${ }^{26}$ oraz modele komponentowe ${ }^{27}$.

Warto zauważyć, że pomimo deklarowanej specyficzności nazw muzycznych emocji estetycznych $\mathrm{w}$ modelu nie znajdziemy nazw emocji specyficznie muzycznych, zawiera on natomiast wiele nazw stanów emocjonalnych odczuwanych na co dzień. Nie wszystkie nazwy odnoszą się także do pojęcia emocji sensu stricto, cześć z nich opisuje afekty, nastroje lub sentymenty ${ }^{28}$. Poziom opisu emocji wskazuje także na różne poziomy ich doświadczania. Ciekawym zabiegiem wydaje się analiza wyróżnionych nazw emocji w kategoriach założeń poznawczo-rozwojowej teorii poziomów świadomości emocji Lane’a i Schwartza ${ }^{29}$.

25 Pomiar dokonany za pomocą stworzonej na podstawie badań 1 i 2 Genewskiej Skali Emocji Muzycznych (Geneva Emotional Music Scale, GEMS); por. M. Zentner i in., Emotions..., op. cit., s. 507.

${ }^{26}$ Pomiar dokonany za pomocą Skali Zróżnicowanych Emocji (Differential Emotions Scale, DES); por. C.E. Izard, Facial Expression and the Regulation of Emotions, „Journal of Personality and Social Psychology" 1990 nr 58, s. 492.

27 Model dwuwymiarowy - koło emocji podzielone jest na segmenty według wymiarów walencji (znaku) i intensywności (pobudzenia); por. J.A. Russel, Core Affect and the Psychological Construction of Emotion, „Psychological Review” 2003 nr 110, s. 148.

28 Por. klasyfikacja zjawisk emocjonalnych według Nico Frijdy w W. Łosiak, Psychologia emocji, Warszawa 2007, s. 25-28.

29 D. Szczygieł, A. Kolańczyk, Skala poziomów świadomości emocji. Adaptacja skali Levels of Emotional Awareness Scale Lane'a i Schwartza, „Roczniki Psychologiczne” 2000 nr 3, s. 155-179. 
Według autorów proces rozwoju świadomości doświadczeń emocjonalnych jest nierozerwalnie związany $\mathrm{z}$ rozwojem poznawczym i przebiega etapowo. Wśród opisów muzycznych emocji estetycznych znajdziemy przykłady do każdego z pięciu wyodrębnionych poziomów świadomości emocji: od zdolności doświadczania emocji w kategoriach zmian somatycznych (pełen energii, pobudzony, spięty) jako tendencji do działania (roztańczony, wstrząśnięty, rozbawiony, rozpłomieniony), poprzez bardziej złożony sposób doświadczania pojedynczych, dobrze wyodrębnionych emocji jako zsynchronizowanych zmian behawioralno-poznawczych (szczęśliwy, pogodny, wesoły, smutny), a także poziom uświadamiania sobie złożoności stanów emocjonalnych jako kombinacji wielu różnych uczuć (uduchowiony, zakochany, nostalgiczny, melancholijny, heroiczny).

Pomimo krytycznych uwag niewątpliwą zaletą badań Zentnera jest wyselekcjonowanie określeń emocjonalnych związanych ze specyficznym kontekstem aktywności człowieka - słuchaniem muzyki, a także ukazanie złożonej struktury powiązań tych określeń. Jak stwierdzają sami autorzy ${ }^{30}$, powstałe $\mathrm{w}$ wyniku tych analiz narzędzie pomiarowe (Genewska Skala Emocji Muzycznych) może być przydatne nie tylko badaczom muzycznych emocji estetycznych, lecz także każdemu, kto zainteresowany jest badaniem wpływu muzyki na emocje (twórcom muzyki, kognitywistom, muzykoterapeutom, marketingowcom, filmowcom).

Dodatkowych dowodów na słuszność założeń modelu dostarczają badania nad neuronalnymi korelatami emocji doświadczanych podczas słuchania muzyki. Wiebke Trost ze współpracownikami ${ }^{31}$ postanowił sprawdzić założenia opisywanego dziewięciowymiarowego modelu emocji muzycznych na gruncie badań nauk o mózgu. Wyniki badań z użyciem metod neuroobrazowania (fMRI) potwierdziły zasadność wyodrębnienia dziewięciu kategorii emocji oraz trzech czynników nadrzędnych. Zauważono również, że odczuwanie emocji estetycznych wiąże się z aktywacją struktur podobnych do tych, które ulegają aktywacji podczas odczuwania emocji codziennych (m.in. w zależności od jakości emocji - układ nagrody, wyspa, prążkowie,

\footnotetext{
${ }^{30}$ M. Zentner i in., Emotions..., op. cit., s. 520.

${ }_{31}$ W. Trost i in., Mapping Aesthetic Musical Emotions in the Brain, „Cerebral Cortex” 2012 nr 22, s. 2769-2783.
}

poszczególne obszary czołowej i przedczołowej kory mózgowej). Jednak emocje estetyczne częściej związane były z aktywacją obszarów niespecyficznych dla emocji - kory motorycznej, struktur związanych z pamięcią (hipokamp, zakręt hipokampa) i procesami autorefleksji (przyśrodkowy zakręt kory obręczy). Te wyniki wraz $z$ wynikami poprzednich badań ${ }^{32}$ wskazują na to, że emocje estetyczne są zjawiskami złożonymi, często związane są z przeżywaniem kilku bardziej podstawowych emocji, a ich treści przetwarzane są na różnych poziomach organizacji mózgu. Opisywane wyniki wymagają odniesienia do wiedzy dotyczącej mechanizmów wzbudzania emocji estetycznych.

\section{ŹRÓDŁA EMOCJI ESTETYCZNYCH I MECHANIZMY ICH WZBUDZANIA}

Analizując terminy używane w badaniach nad emocjami wywołanymi muzyką, Patrik N. Juslin ${ }^{33}$ również zwraca uwagę na potrzebę uporządkowania terminologii. Uwrażliwia badaczy i czytelników na odcienie znaczeniowe terminów używanych do opisu reakcji emocjonalnej na muzykę, wyróżniając: preferencje muzyczne (długoterminowe oceny afektywne o niskiej intensywności, których kluczowy wymiar stanowi walencja - głównie wymiar lubienie/nielubienie), emocje (intensywna, szybka reakcja afektywna w odpowiedzi na bodziec, uruchamiająca systemy reakcji fizjologicznych, behawioralnych i poznawczych) oraz poznawcze oceny estetyczne (subiektywna ocena utworu muzycznego jako dzieła sztuki oparta na zestawie indywidualnych kryteriów oceny).

Na kwestię „subiektywnej ważności” muzyki autor $^{34}$ proponuje spojrzeć z perspektywy ewolucyjno-ekologicznej: dla naszych przodków jednym $\mathrm{z}$ warunków przetrwania była umiejętność dostrzegania

${ }^{32}$ Por. P.G. Hunter, E.G. Schellenberg, U. Schimmack, Mixed Affective Responses to Music with Conflicting Cues, „Cognition and Emotion” 2008 nr 22, s. 342-343, a także F.S. Barrett, K.J. Grimm, R.W. Robins, T. Wildschut, C. Sedikides, P. Janata, Music-Evoked Nostalgia: Affect, Memory, and Personality, „Emotion” $2010 \mathrm{nr}$ 10, s. $400-401$.

${ }^{33}$ P.N. Juslin, From Everyday Emotions to Aesthetic Emotions: Towards a Unified Theory of Musical Emotions, „Physics of Life Reviews” $2013 \mathrm{nr} 10$, s. 236-237.

${ }^{34}$ Ibidem. 
źródła dźwięku, szybkiej jego kategoryzacji oraz przygotowania odpowiedniej reakcji behawioralnej ${ }^{35}$. Nagłe, głośne bodźce dźwiękowe do dziś mają właściwości natychmiastowego przyciągania naszej uwagi i wzbudzania intensywnych emocji. Szereg mechanizmów wyspecjalizowanych w przetwarzaniu informacji dźwiękowo-muzycznych dzielimy $\mathrm{z}$ naszymi przodkami: wokalizacja uważana jest za „proto-narrację"36, posiada bowiem własną strukturę przebiegu i daje możliwość przekazywania treści na poziomie niewerbalnym - emocjonalnym i uczuciowym.

Wychodząc z takich założeń, Juslin przedstawia wielopoziomową teorię przyczynowego uwarunkowania emocji ${ }^{37}$, która wyjaśnia mechanizmy leżące u podstaw emocji doświadczanych w kontakcie z muzyką - zarówno zwykłych, jak i estetycznych. Muzyka może wywoływać emocje za pośrednictwem określonych mechanizmów indukcyjnych, uniwersalnych dla wielu bodźców emotogennych, może także wywoływać emocje estetyczne za pośrednictwem mechanizmu refleksyjnych ocen, opartych na sądach estetycznych. Siedem podstawowych mechanizmów BRECVEM $^{38}$, uruchamiających reakcje emocjonalne $\mathrm{w}$ odpowiedzi na muzykę jako jeden $\mathrm{z}$ wielu możliwych bodźców emotogennych, autor przedstawia w kolejności rozwojowej ze stopniowym wzrostem złożoności poznawczej i emocjonalnej:

1) „Odruch pnia mózgu” jest odpowiedzią na fizyczne właściwości bodźca muzycznego (nagły, głośny, dysonansowy), skutkuje wzrostem poziomu pobudzenia i może wywoływać u słuchacza uczucie zaskoczenia.

2) „Porwanie rytmiczne” pojawia się wtedy, gdy występuje tendencja do synchronizowania rytmu ciała (puls, szybkość oddychania) z mocnym, energetycznym rytmem muzyki, co obok wzrostu pobudzenia

${ }^{35}$ A.D. Patel, Music, Language, and Brain, New York 2008, s. 403-406.

${ }^{36}$ P.N. Juslin, Music and Emotion: Seven Questions, Seven Answers..., op. cit., s. 15-18.

${ }^{37}$ A multi-level theory of emotion causation; por. P.N. Juslin, From Everyday Emotions..., op. cit., s. 257.

${ }^{38}$ Akronim od angielskich nazw mechanizmów - Brain stem reflex, Rhythmic entrainment, Evaluative conditioning, Contagion, Visual imagery, Episodic memory, Musical expectancy; por. P.N. Juslin, D. Västfäll, Emotional Responses to Music: The Need to Consider Underlying Mechanisms, „Behavioral and Brain Sciences” $2008 \mathrm{nr} 31$, s. $562-568$. może wywoływać poczucie wspólnoty i przynależności.

3) „Warunkowanie ewaluacyjne” jest wynikiem częstego współwystępowania fragmentu muzycznego $\mathrm{z}$ innym bodźcem wywołującym emocje. Ze względu na proces warunkowania fragment muzyczny nabiera cech emocjonalnych bodźca (np. wydarzenia), jest odczuwany jako smutny, wesoły, wzniosły lub przerażający.

4) „Zarażanie afektywne” pojawia się u słuchacza wskutek rozpoznania emocji w muzyce i empatycznej reakcji na nią. Podatność na taki transfer emocji możliwa jest prawdopodobnie dzięki temu, że muzyka posiada cechy podobne do mowy ludzkiej i dlatego angażuje nas emocjonalnie.

5) „Wyobraźnia wzrokowa” uruchamiana jest w postaci pewnych obrazów pojawiających się podczas słuchania muzyki. Metaforyczna natura muzyki pozwala uruchomić w odpowiedzi pewne indywidualne schematy wzrokowe, powiązane z doświadczeniami cielesnymi. W takiej sytuacji możemy doświadczać bardzo różnorodnych stanów emocjonalnych - od podstawowych do złożonych.

6) „Pamięć epizodyczna” przechowuje informacje na temat zdarzeń życiowych. Niektóre utwory mogą wywoływać wspomnienia określonych wydarzeń życiowych, a te z kolei mogą generować wiele różnorodnych uczuć, wśród których najczęściej relacjonowanym specyficznym uczuciem jest nostalgia.

7) „Oczekiwania muzyczne” wiążą się z umiejętnością przewidywania na podstawie poprzednich doświadczeń muzycznych dalszego przebiegu utworu. Niespełnienie oczekiwań może wywoływać zaskoczenie, lęk lub ciekawość, a spełnienie - uczucie przyjemności, spokoju i zadowolenia.

Siedem wyróżnionych mechanizmów dobrze opisanych na gruncie psychologii emocji pozwala wyjaśnić powstawanie takich reakcji emocjonalnych podczas słuchania utworów muzycznych, jak gęsia skórka, wpadanie $\mathrm{w}$ trans i zatracanie się $\mathrm{w}$ czasie, powstawanie bliskich skojarzeń między utworem a wydarzeniem życiowym, zanurzanie się we wspomnieniach lub przyjemność ze słuchania znanych, starych utworów.

Odczucia towarzyszące przeżywaniu emocji estetycznych opisywane są zgoła inaczej. Zdaniem Juslina, emocje estetyczne, specyficzne dla muzyki jako 
dziedziny sztuki, powstają na wyższych poziomach funkcjonowania poznawczego, a ich źródłem są indywidualne oceny estetyczne (ang. aesthetic judgement) ${ }^{39}$. Rozpoznanie utworu muzycznego jako dzieła sztuki (a nie np. tła muzycznego do pracy) rozpoczyna proces oceny estetycznej. Właściwości utworu analizowane są pod kątem posiadanych przez słuchacza kryteriów oceny estetycznej. Przyjęte kryteria zależą od wiedzy słuchacza i jego wrażliwości muzycznej. Jako najbardziej uniwersalne autor wymienia: piękno, kunszt wykonania, nowość, styl, przesłanie, ekspresję i emocje. Ocena fragmentu muzycznego jako wyjątkowo pięknego (lub trudnego wykonawczo, oryginalnego, emocjonującego) wywoływać może uczucia zachwytu, podziwu, przerażenia lub mistycznego lęku $\mathrm{u}^{40}$. Zdaniem autora, zaangażowanie procesów niższego rzędu (BRECVEM) nie jest konieczne, choć reakcje wzbudzone w tym systemie mogą informować słuchacza o wartości emocjonalnej utworu, jeśli takie kryterium oceny estetycznej zostanie przez niego przyjęte.

Zaletą teorii jest to, że wyjaśnia ona mechanizm powstawania wielu zjawisk emocjonalnych $\mathrm{w}$ reakcji na muzykę: od najmniej świadomych, a zarazem najbardziej cielesnych form reakcji afektywnej (np. pobudzenie odczuwane jako aktywacja lub fizjologiczne objawy, takie jak ciarki na plecach, gęsia skórka), poprzez emocje podstawowe (smutek, strach) i bardziej złożone reakcje emocjonalne (np. duma, nostalgia), do będących skutkiem poznawczej oceny emocji estetycznych (np. podziw, zachwyt). Zestawienie obydwu mechanizmów (indukcyjnego i refleksyjnego) pozwala także wyjaśnić powstawanie emocji mieszanych (np. przyjemnego smutku) w odpowiedzi na muzykę.

Na gruncie psychologii emocji opisane mechanizmy można odnieść do dwusystemowego modelu emocji Marii Jarymowicz i Kamila Imbira ${ }^{41}$ jako współczesnego przykładu pogodzenia kwestii spornych dotyczących współzależności emocji

\footnotetext{
39 P.N. Juslin, From Everyday Emotions..., op. cit., s. 246.

${ }^{40}$ Trudno dokładnie przełożyć na język polski angielską nazwę emocji awe, która zawiera w sobie mieszankę zachwytu i lęku w obliczu wielkości i doskonałości dzieła.

${ }^{41}$ M. Jarymowicz, K. Imbir, Próba taksonomii ludzkich emocji, „Przegląd Psychologiczny” 2010 t. 53 nr 4, s. 456-458; M. Jarymowicz, K. Imbir, Toward a Human Emotions Taxonomy (Based on Their Automatic vs. Reflective Origin), „Emotion Review” 2015 t. 7 nr 2, s. 185 .
}

i poznania ${ }^{42}$. Model uwzględnia dwa rodzaje emocji powstających $\mathrm{w}$ dwóch odrębnych systemach wartościowania - automatycznym i refleksyjnym. Afekty pierwotne (oparte na ocenie automatycznej, podlegające warunkowaniu) są „automatycznymi reakcjami emocjonalnymi na bodźce, niewymagającymi świadomości ich źródeł, a nawet przejawów własnych emocji" ${ }^{43}$. Afekty wtórne powstają w systemie refleksyjnym i oparte są na zwerbalizowanych standardach ewaluacyjnych. W tym przypadku ocena poznawcza poprzedza powstawanie emocji, a walencja i modalność emocji zależą od wyniku oceny. W kategoriach tej teorii wyodrębniony przez Juslina model BRECVEM trafnie opisuje mechanizmy powstawania emocji pierwotnych, podstawowych w reakcji na muzykę, z kolei mechanizm poznawczych ocen estetycznych - emocji wtórnych, złożonych.

\section{PODSUMOWANIE: MUZYCZNE EMOCJE ESTET YCZNE, EMOCJE ESTETYCZNE CZY PO PROSTU EMOCJE?}

Na koniec rozważań warto przedstawić argument funkcjonalny, który pomógłby w rozstrzygnięciu kwestii specyficzności muzycznych emocji estetycznych. Według raportu „Muzykowanie w Polsce”, ukazującego podstawowe formy muzycznej aktywności Polaków ${ }^{44}$, słuchanie muzyki jest częstym sposobem spędzania czasu wolnego zarówno przez osoby niemuzykujące, jak i muzykujące (odpowiednio 54\% i 93\% respondentów z poszczególnych grup wybrało ten rodzaj aktywności). Obserwacje życia codziennego potwierdzają tę prawidłowość - w przestrzeni publicznej zauważamy wiele osób słuchających muzyki podczas rozmaitych codziennych aktywności, muzyka nieodzownie towarzyszy też ważnym wydarzeniom naszego życia.

${ }^{42}$ Spór ten w latach osiemdziesiątych XX wieku zainicjował falę badań nad daną kwestią, a zapoczątkowany został ukazaniem się publikacji: R.B. Zajonc, Feeling and Thinking: Preferences Need No Inferences, „American Psychologist” 1980 t. 35 nr 2, s. 152 i R. Lazarus, Thoughts on the Relations between Emotion and Cognition, „American Psychologist" $1982 \mathrm{nr} 37$, s. 1019.

${ }^{43}$ K. Imbir, M. Rutniewska, Rola emocji (automatycznych vs. refleksyjnych) $w$ procesach intuicyjnych ocen społecznych, „Psychologia Społeczna" 2014 t. 9 nr 4, s. 456.

${ }_{44}$ A. Białkowski i in., Muzykowanie w Polsce. Badanie podstawowych form aktywności muzycznej Polaków, Warszawa 2014, s. 45. 
Wygląda na to, że słuchanie muzyki ma szereg funkcji ważnych dla podmiotu. Jeśli spojrzymy na emocje wywołane muzyką na poziomie mechanizmów niższego rzędu (BRECVEM), to funkcje te będą podobne do tych, jakie emocje pełnią na co dzieńt ${ }^{45}$ energetyzująco-pobudzająca, motywacyjna (związana z przygotowaniem i ukierunkowaniem działania), orientacyjna i wartościująca (emocje mają wpływ na ocenę bodźców i sytuacji), komunikacyjna (przekazywanie innym informacji o swoim stanie emocjonalnym za pomocą mimiki i zachowania) oraz regulacyjna (emocje mogą zmieniać nasze samopoczucie i wpływać na interakcję z otoczeniem). Słuchanie muzyki pełni także szereg funkcji społecznych - daje poczucie wspólnoty i przynależności, preferencje muzyczne są często ważnym wymiarem tożsamości, zwłaszcza w okresie adolescencji stają się formą autoekspresji ${ }^{46}$.

Wszelkie te funkcje wykorzystywane są aktywnie m.in. $\mathrm{w}$ muzykoterapii ${ }^{47} \mathrm{w}$ celach leczniczych i rozwojowych oraz $\mathrm{w}$ audiomarketingu jako narzędzie zmiany zachowań konsumenckich ${ }^{48}$. W tym przypadku muzyka jednak traktowana jest przez słuchacza instrumentalnie ${ }^{49}$ jako narzędzie do zmiany nastroju, wspomagania myślenia, energetyzacji zachowania, pozwala zaspokoić potrzeby niższego rzędu (np. biologiczne i fizjologiczne, przynależności $)^{50}$.

45 K.R. Scherer, What Are Emotions?..., op. cit., s. 698.

46 R. Lawendowski, Osobowościowe uwarunkowania preferencji muzycznych $w$ zależności od wieku, Kraków 2011, s. 217-219; R. Lawendowski, Homo musicus. Muzyka w relacjach społecznych, [w:] Psychologia muzyki. Współczesne konteksty zastosowań, red. R. Lawendowski, J. Kaleńska-Rodzaj, Gdańsk 2014, s. 27-28.

${ }^{47}$ Por. E. Klimas-Kuchtowa, Muzyka $w$ prewencji $i$ promocji zdrowia, [w:] Psychologia muzyki. Współczesne konteksty zastosowań, red. R. Lawendowski, J. Kaleńska-Rodzaj, Gdańsk 2014, s. 168 -170, a także I. Poćwierz-Marciniak, M. Kierzkowski, Muzyka a zmiana nastroju u osób chorych somatycznie będących $w$ trakcie hospitalizacji, [w:] Psychologia muzyki. Pomiędzy wykonawca a odbiorca, red. J. Kaleńska-Rodzaj, R. Lawendowski, Gdańsk 2015, s. 134-135.

48 Por. S. Makomaska, Droga do „makdonaldyzacji”..., op. cit., s. 156 .

49 Istnienie dwóch podstawowych mechanizmów motywacyjnych człowieka - motywacji autonomicznej (wewnętrznej) vs. instrumentalnej (zewnętrznej) - postulują twórcy teorii autodeterminacji: E.L. Deci, R.M. Ryan, Intrinsic Motivation and Self-Determination in Human Behavior, New York 1985, s. 32-34; E.L. Deci, R.M. Ryan, The "What" and "Why" of Goal Pursuits: Human Needs and the Self-Determination of Behavior, „Psychological Inquiry” 2000 nr 11, s. 227-228, 232-233.

50 Zestawienie $\mathrm{w}$ odniesieniu do hierarchii potrzeb wyróżnionych przez Abrahama Maslowa; por. A.H. Maslow, A Theory of Human Motivation, „Psychological Review” 1943 t. 50 nr 4, s. 376-382.
Emocje estetyczne wyższego rzędu, powstające $\mathrm{w}$ systemie refleksyjnym, odzwierciedlają światopogląd i wartości respektowane przez słuchacza. Silne doświadczenia muzyczne mają funkcję „katartyczną”, "transcendentną", często otwierają przed nami nowe drogi rozwoju ${ }^{51}$. Te funkcje wskazują na chęć słuchania muzyki dla niej samej, traktowania jej jako wartości samej w sobie - odkrywania jej znaczeń, piękna, formy (procesy regulacyjne mogą oczywiście zachodzić automatycznie, lecz nie stanowią celu podejmowania aktywności). W tym przypadku zaspokajamy potrzeby wyższego rzędu - poznawcze, estetyczne (!), a także samorealizacji i transcendencji. Obcowanie ze sztuką daje słuchaczowi możliwość odkrycia i doświadczenia emocjonalnego trzech najważniejszych wartości - estetycznej (piękno), poznawczej (prawda) i etycznej (dobro). W świetle tych wartości słuchacz może dokonać refleksji nad własnym życiem i wzbogacić je o nowe wartości duchowe. W ten sposób emocje estetyczne prowadzą do zmiany i rozwoju indywidualnego, a w konsekwencji i społecznego.

Podsumowując całość, przedstawiony przegląd badań nad emocjami estetycznymi dokonany z perspektywy psychologicznej stanowi swoiste zaproszenie dla czytelników muzyków lub muzykologów. Opiera się on na pracach ukazujących empiryczne próby weryfikacji założeń dotyczących specyficzności zjawiska emocji estetycznych, a w szczególności muzycznych emocji estetycznych. Zakładano, że takim dowodem będzie ukazanie specyficznych terminów używanych do opisu przeżyć wywołanych muzyką, specyficznych mechanizmów wzbudzania emocji oraz unikalnych funkcji tych emocji pełnionych w życiu odbiorcy. Tymczasem wygląda na to, że do opisu emocji wywołanych muzyką używamy określeń często spotykanych w życiu codziennym, w reakcji na inne bodźce emotogenne. Szereg określeń można uznać za specyficzne opisy reakcji na piękno (zachwyt), harmonię i doskonałość (spokój ducha, podziw), a także coś, co przekracza nasze oczekiwania (wzruszenie, poczucie mocy lub przytłoczenia), lecz warto zauważyć, że określenia te nie są zarezerwowane wyłącznie dla

\footnotetext{
51 Por. A. Gabrielsson, Emotions in Strong Experiences with Music..., op. cit., s. 436; A. Gabrielsson, S. Lindström Wik, Strong Experiences Related to Music..., op. cit., s. 180-182; B. Kamińska, Znaczace przeżycia muzyczne $w$ relacjach młodzieży..., op. cit., s. 193; J.A. Sloboda, Poznanie, emocje, wykonanie..., op. cit., s. 37.
} 
domeny sztuki (mogą być wzbudzane np. przez naturę), a tym bardziej muzyki.

Wygląda na to, że mechanizmy wzbudzania emocji w odpowiedzi na muzykę łatwo dają się odnieść do ogólnej wiedzy psychologicznej na temat mechanizmów powstawania emocji podstawowych (system automatyczny) oraz złożonych (system refleksyjny). To, co wyróżnia emocje estetyczne, to określony zestaw kryteriów oceny (piękno, kunszt wykonania, nowość, styl, przesłanie, ekspresja i emocje) odpowiedzialny za rozpoznanie bodźca jako estetycznego i uruchomienie reakcji emocjonalnej, której intensywność będzie zależna od stopnia spełniania kryteriów. Warto zauważyć, że paradoksalnie najsilniejsze reakcje emocjonalne pojawią się prawdopodobnie $\mathrm{w}$ momencie znaczącego przekroczenia oczekiwań - ta antynomiczna natura doświadczenia wpisana jest w pojęcie twórczości ${ }^{52}$. W momencie, gdy kryteria oceny zostaną przekroczone w kierunku negatywnym, pojawi się intensywne uczucie obrzydzenia, nieczęsto uwzględniane w skalach do pomiaru emocji estetycznych ${ }^{53}$.

Jeśli chodzi o aspekty funkcjonalne, to do najbardziej specyficznych funkcji emocji estetycznych należy rozwój (otwartość na nowość, docenianie nowości, włączanie nowych informacji o świecie do systemu wiedzy ${ }^{54}$ ) oraz transcendencja (przekraczanie granic własnego Ja, poczucie jedności $\mathrm{z}$ absolutem).

$\mathrm{Na}$ podstawie przeanalizowanej literatury stwierdzam, że nie ma wystarczających dowodów na istnienie specyficznej kategorii „muzycznych emocji estetycznych". To pojęcie dotyczy określonego kontekstu aktywności człowieka (słuchania muzyki), w którym emocje estetyczne są odczuwane. Jednak stwierdzenie, że emocje estetyczne nie różnią się od emocji podstawowych, odczuwanych na co dzień, również wydaje się zbyt radykalne. W ślad za Juslinem proponowałabym zatem zarezerwować pojęcie emocji

52 A.J. Cropley, Creativity: A Bundle of Paradoxes, „Gifted and Talented International" $1997 \mathrm{nr}$ 12, s. 9-15.

${ }_{53}$ Por. analizy P.J. Silvia, Looking Past Pleasure: Anger, Confusion, Disgust, Pride, Surprise, and Other Unusual Aesthetic Emotions, "Psychology of Aesthetic, Creativity and Arts” 2009 nr 3 (1), s. 48-51, a także analizy i narzędzie w I. Schindler, G. Hosoya, W. Menninghaus i in., Measuring Aesthetic Emotions: A Review of the Literature and a New Assessment Tool, „PLoS ONE” $2017 \mathrm{nr} 12$ (6).

${ }^{54} \mathrm{~W}$ ten sposób funkcje emocji zachwytu i mistycznego lęku (ang. awe) opisują M.N. Shiota i in., Positive Emotion Differentiation: A Functional Approach, „Social and Personality Psychology Compass" $2014 \mathrm{nr} 8$, s. 108-109, 111. estetycznych dla wąskiej kategorii emocji złożonych, powstających w systemie refleksyjnym wskutek oceny poznawczej bodźców pod kątem subiektywnych kryteriów estetycznych posiadanych przez odbiorcę. Niestety, ustalenie uniwersalanych kryteriów oceny estetycznej od dawna było i wciąż pozostaje wyzwaniem dla sztuki i nauki.

\section{BIBLIOGRAFIA}

Barrett Frederick S., Grimm Kevin J., Robins Richard W., Wildschut Tim, Sedikides Constantine, Janata Petr, $\mathrm{Mu}$ sic-Evoked Nostalgia: Affect, Memory, and Personality, „Emotion” 2010 nr 10, s. 390-403.

Białkowski Andrzej, Migut Mateusz, Socha Ziemowit, Wyrzykowska Katarzyna M., Muzykowanie w Polsce. Badanie podstawowych form aktywności muzycznej Polaków, Fundacja na rzecz rozwijania muzykalności Polaków „Muzyka jest dla wszystkich", Warszawa 2014.

Chełkowska-Zacharewicz Maria, Janowski Maciej, Polska adaptacja Geneva Emotional Music Scale (GEMS) - badania wstępne, „Polskie Pismo Muzykoterapeutyczne” 2016 nr 3, s. 44-64.

Cropley Artur J., Creativity: A Bundle of Paradoxes, „Gifted and Talented International" $1997 \mathrm{nr}$ 12, s. 9-15.

Deci Edward L., Ryan Richard M., Intrinsic Motivation and SelfDetermination in Human Behavior, Springer, New York 1985.

Deci Edward L., Ryan Richard M., The "What" and "Why" of Goal Pursuits: Human Needs and the Self-Determination of Behavior, „Psychological Inquiry” 2000 nr 11, s. 227-268.

Ekman Paul, An Argument for Basic Emotions, „Cognition and Emotion" 1992 nr 6, s. 169-200.

Gabrielsson Alf, Emotions in Strong Experiences with Music, [w:] Music and Emotion. Theory and Research, red. Patrik N. Juslin, John A. Sloboda, Oxford University Press, Oxford 2001, s. 431-449.

Gabrielsson Alf, Emotion Perceived and Emotion Felt: Same or Different?, „Musicae Scientiae” 2002 t. 5 nr 1, s. 123-147.

Gabrielsson Alf, Lindström Wik Siv, Strong Experiences Related to Music: A Descriptive System, „Musicae Scientiae” 2003 t. 7 nr 2, s. 157-217.

Gołaszewska Maria, Kim jest artysta?, Wydawnictwa Szkolne i Pedagogiczne, Warszawa 1986.

Hunter Patrick G., Schellenberg E. Glenn, Schimmack Ulrich, Mixed Affective Responses to Music with Conflicting Cues, „Cognition and Emotion” 2008 nr 22, s. 327-352. 
Imbir Kamil, Rutniewska Magdalena, Rola emocji (automatycznych vs. refleksyjnych) $w$ procesach intuicyjnych ocen społecznych, „Psychologia Społeczna” 2014 t. 9 nr 4, s. $455-465$.

Izard Caroll E., Basic Emotions, Natural Kinds, Emotion Schemas, and a New Paradigm, „Perspectives on Psychological Science" 2007 nr 2, s. 260-280.

Izard Caroll E., Facial Expression and the Regulation of Emotions, „Journal of Personality and Social Psychology” 1990 nr 58, s. 487-498.

Jarymowicz Maria, Imbir Kamil, Próba taksonomii ludzkich emocji, „Przegląd Psychologiczny” 2010 t. 53 nr 4, s. 439-461.

Jarymowicz Maria, Imbir Kamil, Toward a Human Emotions Taxonomy (Based on Their Automatic vs. Reflective Origin), „Emotion Review” 2015 t. 7 nr 2, s. 183-188.

Juslin Patrik N., From Everyday Emotions to Aesthetic Emotions: Towards a Unified Theory of Musical Emotions, „Physics of Life Reviews” 2013 nr 10, s. 235-266.

Juslin Patrik N., Music and Emotion: Seven Questions, Seven Answers, [w:] Music and the Mind: Essays in Honour of John Sloboda, red. Irene Deliège, Jane Davidson, Oxford University Press, Oxford 2011, s. 113-135.

Juslin Patrik N., Laukka Petri, Expression, Perception, and Induction of Musical Emotions: A Review and a Questionnaire Study of Everyday Listening, „Journal of New Music Research" 2004 nr 33, s. 217-238.

Juslin Patrik N., Västfäll Daniel, Emotional Responses to $\mathrm{Mu}$ sic: The Need to Consider Underlying Mechanisms, „Behavioral and Brain Sciences” 2008 nr 31, s. 559-575.

Kamińska Barbara, Znaczace przeżycia muzyczne w relacjach młodzieży, [w:] Powszechna edukacja muzyczna a wyzwania współczesności, red. Andrzej Białkowski, Wydawnictwo UMCS, Lublin 2000, s. 151-164.

Kivy Peter, Music Alone: Philosophical Reflections on the Purely Musical Experience, Cornell University Press, Ithaca 1990.

Klimas-Kuchtowa Ewa, Muzyka w prewencji i promocji zdrowia, [w:] Psychologia muzyki. Współczesne konteksty zastosowań, red. Rafał Lawendowski, Julia Kaleńska-Rodzaj, Harmonia, Gdańsk 2014, s. 159-184.

Konecni Vladimir J., The Aesthetic Trinity: Awe, Being Moved, Thrills, „Bulletin Psychology and the Arts” 2005 nr 5, s. $27-44$.

Laukka Petri, Uses of Music and Psychological Well-Being among the Elderly, „Journal of Happiness Studies” 2007 nr 8, s. 215-241.

Lawendowski Rafał, Homo musicus. Muzyka $w$ relacjach społecznych, [w:] Psychologia muzyki. Współczesne konteksty zastosowań, red. Rafał Lawendowski, Julia Kaleńska-Rodzaj, Harmonia, Gdańsk 2014, s. 15-39.

Lawendowski Rafał, Osobowościowe uwarunkowania preferencji muzycznych w zależności od wieku, Impuls, Kraków 2011.

Lazarus Richard, Thoughts on the Relations between Emotion and Cognition, „American Psychologist” $1982 \mathrm{nr} 37$, s. 1019-1024.

Levinson Jerrold, Music and Negative Emotion, [w:] Music and Meaning, red. Jenefer Robinson, Cornell University Press, Ithaca-London 1997, s. 215-241.

Lewis Michael, Wyłanianie się ludzkich emocji, [w:] Psychologia emocji, red. Michael Lewis, Jeannette Haviland-Jones, przekład zbiorowy, Gdańskie Wydawnictwo Psychologiczne, Gdańsk 2005, s. 342-360.

Łosiak Władysław, Psychologia emocji, Wydawnictwa Akademickie i Profesjonalne, Warszawa 2007.

Makomaska Sylwia, Droga do „makdonaldyzacji” doświadczenia stuchowego - refleksja nad obecnościa muzyki tła $w$ przestrzeni komercyjnej, [w:] Psychologia muzyki. Pomiędzy wykonawca a odbiorca, red. Julia Kaleńska-Rodzaj, Rafał Lawendowski, Harmonia, Gdańsk 2015, s. 151-164.

Maslow Abraham H., A Theory of Human Motivation, „Psychological Review” 1943 t. 50 nr 4, s. 370-396.

Maslow Abraham H., Toward a Psychology of Being, Van Nostrand Reinhold, New York 1968.

Meyer Leonard B., Emocja i znaczenie w muzyce, przeł. Antoni Buchner, Karol Berger, Polskie Wydawnictwo Muzyczne, Kraków 1974.

Patel Aniruddh D., Music, Language, and Brain, Oxford University Press, New York 2008.

Poćwierz-Marciniak Ilona, Kierzkowski Michał, Muzyka a zmiana nastroju u osób chorych somatycznie będacych $w$ trakcie hospitalizacji, [w:] Psychologia muzyki. Pomiędzy wykonawca a odbiorca, red. Julia Kaleńska-Rodzaj, Rafał Lawendowski, Harmonia, Gdańsk 2015, s. 133-150.

Russell James A., Core Affect and the Psychological Construction of Emotion, „Psychological Review” 2003 nr 110, s. $145-172$.

Scherer Klaus R., Emotion as a Process: Function, Origin, and Regulation, „Social Science Information” 1982 nr 21, s. 555-570.

Scherer Klaus R., What Are Emotions? And How Can They Be Measured?, „Social Science Information” 2005 nr 44, s. 695-729.

Scherer Klaus R., Which Emotions Can Be Induced by Music? What Are the Underlying Mechanisms? And How Can We 
Measure Them?, „Journal of New Music Research” 2004 nr 33, s. 239-251.

Schindler Ines, Hosoya Georg, Menninghaus Winfried, Beermann Ursula, Wagner Valentin, Eid Michael, Scherer Klaus R., Measuring Aesthetic Emotions: A Review of the Literature and a New Assessment Tool, „PLoS ONE” 2017 nr 12 (6).

Shiota Michelle N., Neufeld Samantha L., Danvers Alexander F., Osborne Elisabeth A., Sng Oliver i Yee Claire I., Positive Emotion Differentiation: A Functional Approach, "Social and Personality Psychology Compass” 2014 nr 8, s. 104-117.

Silvia Paul J., Looking Past Pleasure: Anger, Confusion, Disgust, Pride, Surprise, and Other Unusual Aesthetic Emotions, „Psychology of Aesthetic, Creativity and Arts” 2009 nr 3 (1), s. 48-51.

Sloboda John A., Poznanie, emocje, wykonanie - trzy wykłady z psychologii muzyki, przeł. Andrzej Miśkiewicz, Akademia Muzyczna Fryderyka Chopina, Warszawa 1999.

Szczygieł Dorota, Kolańczyk Alina, Skala poziomów świadomości emocji. Adaptacja skali Levels of Emotional Awareness Scale Lane'a i Schwartza, „Roczniki Psychologiczne” 2000 nr 3, s. 155-179.

Trost Wiebke, Ethofer Thomas, Zentner Marcel, Vuilleumier Patrik, Mapping Aesthetic Musical Emotions in the Brain, „Cerebral Cortex” 2012 nr 22, s. 2769-2783.

Wierzbicka Anna, Emotions across Languages and Cultures, Cambridge University Press, Cambridge 1999.

Zajonc Robert B., Feeling and Thinking: Preferences Need No Inferences, „American Psychologist” 1980 t. 35 nr 2, s. 151-175.

Zentner Marcel, Grandjean Didier, Scherer Klaus R., Emotions Evoked by the Sound of Music: Characterization, Classification, and Measurement, „Emotion” 2008 t. 8 nr 4, s. 494-521.

\section{SUMMARY}

\section{Julia Kaleńska-Rodzaj}

\section{Aesthetic emotions in light of research into the psychology of music: a description and explanatory mechanisms.}

The main aim of this article is to review contemporary research on aesthetic emotions from the perspective of music psychology. By analyzing the results of research review in the broader theoretical context, the author attempts to answer the question of the appropriateness of distinguishing a separate category of aesthetic emotions and musical aesthetic emotions. She concludes that despite the specific terminology used to describe aesthetic musical emotions (classification of aesthetic emotions by M. Zentner et al.), some specific induction mechanisms (a multi-level theory of emotion causation by P.N. Juslin) and functions fulfilled in the listener's life, there is no clear evidence to distinguish musical aesthetic emotions as a separate category of emotions, and the term aesthetic emotions should be reserved only for the emotions arising as a result of the cognitive evaluation of the stimulus according the listener's aesthetic criteria.

\section{Keywords}

aesthetic emotions, aesthetic judgements, basic emotions, emotion induction mechanisms, music listening 